\title{
Giant Cell Tumor: Cyst of the Intercondylar Fossa of the Knee (A Reported Case) \\ H. Filali Baba ${ }^{1 *}$, M. Lahsika ${ }^{1}$, D. Oudrhiri ${ }^{1}$, H. Abid ${ }^{1}$, M. El Idrissi ${ }^{1}$, A. El Ibrahimi ${ }^{1}$, A. Elmrini ${ }^{1}$
}

${ }^{1}$ Service Traumatologie Orthopédie B4, CHU Hassan II De Fes, Centre Hospitalier Hrazem, BP:1835 Atlas, Fès ‘Avenue Hassan II, Fes 30050, Morocco

DOI: $10.36347 /$ sjmcr.2021.v09i03.016

| Received: 24.01.2021 | Accepted: 10.02.2021 | Published: 17.03.2021

*Corresponding author: H. Filali Baba

Abstract

Case Report

Giant cell tumors of the synovial sheaths (GCTSS), or tenosynovial giant cell tumor, or hemopigmented villonodular synovitis, develop from the articular and periarticular synovium. LVPS may be clinically indistinguishable from meniscal injury or other internal disturbance. This lesion is histologically identical to its diffuse counterpart but has a different behavior and response to treatment. MRI usually reveals a variable-sized of nodule with a decreasing heterogeneous signal on T1-weighted and T2-weighted images.In arthroscopy; there is a slightly pigmented synovial mass; with punctate purpura if the tourniquet is swollen, in the absence of other lesions should alert the surgeon of the diagnosis. The treatment consists of a wide-marginal arthroscopic resection, the prognosis of which is excellent if it is complete.

Keywords: Knee, Intercondylar Fossa Cyst, giant cell tumor.

Copyright $(\mathcal{C} 2021$ The Author(s): This is an open-access article distributed under the terms of the Creative Commons Attribution 4.0 International License (CC BY-NC 4.0) which permits unrestricted use, distribution, and reproduction in any medium for non-commercial use provided the original author and source are credited.

\section{INTRODUCTION}

Giant cell tumors of the synovial sheaths (GCTSS), or tenosynovial giant cell tumor, or hemopigmented villonodular synovitis, develop from the articular and periarticular synovium. These tumors constitute a benign proliferative disorder of the synovium, the etiopathogenesis of which remains undetermined. The most widely accepted theory is that proposed by Jaffé et al., [1] which suggests reactive or regenerative hyperplasia of the synovium secondary to an inflammatory process.

We report a case of a GCT with the same clinical characteristics and even on magnetic resonance imaging.

\section{Clinical Case}

A 56-year-old patient, sedentary, consulted for posterior pain of mechanical rhythm of the right knee with effusion during the efforts for six months without a triggering factor found and without any notion of instability. On clinical examination the pain was of nonspecific posterior position limiting passive and active flexion from 90 degrees of flexion. The patient was in genu-varum at 2TDD. Absence of laxity in the frontal and sagittal planes.
The x-ray did not find any bone lesion. In order to complete the assessment, an MRI was written and objectified a mass of $18 \mathrm{~mm}$ long axis at the level of the intercondylar notch of long axis contiguous to the proximal part of the anterior cruciate ligament (Fig-1) well limited, heterogeneous hypersignal in PD FS, hyposignal in $\mathrm{T} 1$, and is heightened in a homogeneous manner after injection, evoke a mucoid cyst of the intercondylar fossa of the knee. A surgical indication for arthroscopic treatment of the lesion was retained.

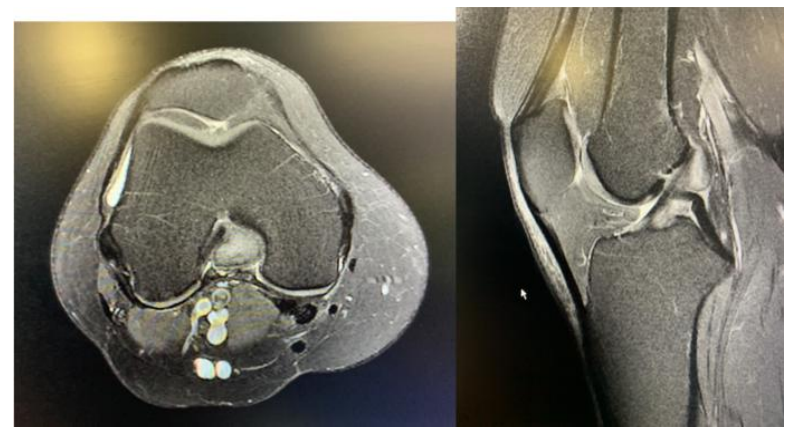

Fig-1 : MRI: mass of $18 \mathrm{~mm}$ long axis at the level of the intercondylar notch of long axis contiguous to the proximal part of the ACL well limited, heterogeneous hypersignal in PD FS, hyposignal in $\mathrm{T} 1$, and is heightened in a homogeneous manner after injection, evoke a mucoid cyst of the intercondylar fossa of the knee 
The operation was performed under spinal anesthesia in the dorsal decubitus position with a pneumatic tourniquet by conventional methods. The exploration finds a stage I chondropathy in the patella, the rest of the knee compartments are intact, the meniscus are intact, the anterior cruciate ligament is a little effit but well stretched, we will pass our arthroscope posteriorly: we visualize the tumor which is in the indentation and which is fleshy yellow-brown in appearance, we take a biopsy of the tumor. Complete resection of the lesion by arthroscopic posterointernally with the basket clamp and during this resection the anterior cruciate ligament was damaged and became partly effective. After resection, the mobile fragment was sent for pathology. Histological analysis found a dual aspect characteristic of a giant cell tumor of the tendon sheaths: densely cellular lesion made on the one hand by sectors of spindle cells without notable atypia, on the other hand, we observe a few multinucleated giant cells. histiocytic type. There is a little brownish hemosiderin pigment within the lesion.

Full immediate support was authorized with flexion limitation to $90^{\circ}$ for 1 month. At the clinical check-up at 1 month, the symptoms had disappeared.

\section{DISCUSSION}

Pigmented villonodular synovitis is a benign synovial proliferation of unknown etiology. Myers and Masi [2] calculated the annual incidence to be between 1.8 and 9.2 cases per million. Dorfman [3] and LopezVazquez et al., [4] estimated the frequency of LPVNS to be 1 in 2,500 arthroscopies. Bravo et al., [5] examined 190 cases of PVNS, of which only 6\% were localized forms. PVNS affects both males and females, although most of our patients are males in the third and fourth decades of life [6-10] and 67\% of cases are the knee, according to one study by Monghal et al., [11].

In most of the diffuse forms, the diagnosis does not pose a problem in front of an evocative picture (repeated hemarthrosis with pain then stiffness, radiographic mirror geodes, cortical erosions, osteoarthritis) [13, 14].

For certain diffuse forms and especially for localized forms, the observation of non-specific symptoms makes the diagnosis difficult. The discomfort is constant but the clinical presentation can be variable: blockage (30 to $100 \%$ ), effusion (53 to $90 \%$ ), diffuse pain (66 to $100 \%)$, decrease in mobility (45\%), palpation of a mass (11 to $80 \%$ ) or pain next to the line spacing which may suggest a meniscal lesion (10 to $34 \%)$ [14, 6-8, 13]. Clinic may also suggest an intraarticular free foreign body [16] and symptoms related to associated cartilage damage are possible $[11,17]$.

Thus, although as early as 1967, Granowitz and Mankin 7 informed of the need to evoke localized VNS in the event of mechanical disturbance of the knee with episodic pain or blockage 7 , the preoperative diagnosis of meniscal lesion is retained in $30 \%$ of cases of PVNS. 6 and for Pinaroli et al., [18], the diagnosis of SVN was mentioned in only $25 \%$ of localized forms.

In PVNS, the $\mathrm{x}$-ray may rarely find geodes but is very often normal [18]. Although X-rays of the knee tend to be normal [19], the characteristic images described by McMaster [20] can be seen in advanced cases: round, ovaloid geodes or finger-forms surrounded by a thin sclera halo on both sides of the common line. These appear between $16 \%$ and $67 \%$ [21] of the diffuse forms. Sometimes small cystic formations or cortical erosion can be seen in LPVNS [22-24].

MRI usually reveals a nodule of varying size with a decreasing heterogeneous signal on both T1weighted and T2-weighted images [7, 25, 26]. This is due to the ferromagnetic properties of hemosiderin, which causes a shortened relaxation time in $\mathrm{T} 1$ weighting and $\mathrm{T} 2$ weighting. This effect depends on the hemosiderin concentration [27].

MRI is also the technique of choice in cases of suspected recurrence $[5,7,25]$. Although MRI significantly assists in the identification of PVNS, it is not specific and the differential diagnosis with synovial chondromatosis, synovial hemangioma, rheumatoid arthritis, hemophilic arthropathy, amyloid arthropathy, and desmoid tumor should be performed [5, 6, 23, 26].

The rate of recurrence of the diffuse form is related to whether the synovectomy is complete $[8,25$, 31]. Excellent results are obtained by excising the nodule and synovectomy of the implantation base [6, $12,14,21,22,28]$. The Tiec et al., [25] reported a case of recurrence of the localized form in which the base had not been completely removed.

Excision of localized forms of PVNS is the rule [23]. As the morbidity is lower, the arthroscopic technique should be preferred, provided that the entire lesion can be removed. After arthroscopic resection, Dines et al. (5) report $90 \%$ excellent results for the Lysholm score at 5 years and Rhee et al., [2] found an average Ogilvie-Harris score of 8 to 9 years of followup. The recurrence rate after arthroscopic resection is $0 \%$ for mean decline of 3 to 5 years $[5,18,28,29]$ except for Rhee et al., [2] who report $18 \%$ recurrence (2 cases out of 11, with a delay of 6 and 9 months postoperatively). Cauterization and complete excision of the foot of the lesion would decrease the risk of recurrence $[15,30]$.

Finally, if a meniscal lesion is associated with PVNS, the treatment of both lesions is done at the same time [5, 31]. In our case, we resected the PVNS arthroscopically and sutured the meniscal disinsertion induced by resection of the foot of the lesion. 


\section{CONCLUSION}

LVPS may be clinically indistinguishable from a meniscal injury or other internal derangement. Thelesion is histologically identical to its diffuse counterpart but has a contrastiing behavior and response to treatment. Arthroscopic findings of a mildly pigmented synovial mass; with punctate purpura if the tourniquet is inflated, in the absence of other evidence of injury should alert the arthroscopist to the diagnosis. The prognosis after arthroscopic wide-marginal resection should be excellent if careful attention is given to complete resection.

\section{BIBLIOGRAPHIES}

1. Jaffe HL, Lichtenstein L, Sutro CJ. Pigmented villonodular synovitis, bursitis and tenosynovitis. Arch Pathol. 1941;31:731-765.

2. Myers BW, Masi AT. Pigmented villonodular synovitis and tenosynovitis: A clinical epidemiologic study of 166 cases and literature review. Medicine. 1980; 19:223-238.

3. Dorfman H. Arthroscopic recognition of synovial disorders. Contemp Orthop. 1985;10:19-29.

4. Lopez-Vazquez E, Lopez-Peris JL, Vila-Donat E, Martinez-Garcia JB, Bru-Pomer A. Localized pigmented villonodular synovitis of the knee: Diagnosis and arthroscopic resection. Arthroscopy: The Journal of Arthroscopic \& Related Surgery. 1988 Jan 1;4(2):121-3.

5. Bravo SM, Winalski CS, Weissman BN. Pigmented villonodu- lar synovitis. Radiol Clin North Am. 1996;34:311-326.

6. Bravo SM, Winalski CS, Weissman BN. Pigmented villonodu- lar synovitis. Radiol Clin North Am. 1996;34:311-326.

7. Kim SJ, Shin SJ, Choi NH, Choo ET. Treatment for localized pigmented villonodular synovitis of the knee. Clin Orthop. 2000;379:224-230.

8. Garcia Sanchez A, Utrilla Utrilla M, Casals Sanchez JL, et al. Sinovitis vellonodular pigmentada con presentacion poliarticular. Ann Med Int 1996;13:341-343.

9. Le Tiec T, Hulet C, Locker B, Béguin J, Vielpeau C. La synovite, villonodulaire du genou: Analyse d'une série de 17 cas et revue de la littérature. Revue de chirurgie orthopédique et réparatrice de l'appareil moteur. 1998;84(7):607-16.

10. Rao AS, Vigorita VJ. Pigmented villonodular synovitis (giant cell tumor of the tendon sheath and synovial membrane): A review of eighty-one cases. J Bone Joint Surg Am. 1984;66:76-94.

11. Monghal JP. Contribution a l'etude de la synovite villonodulaire du genou. Rev Rhum Mal Osteoartic. 1981;48:397-402.

12. Ogilvie-Harris DJ, McLean J, Zarnett ME. Pigmented vil-lonodular synovitis of the knee. The results of total arthro- scopic synovectomy, partial, arthroscopic synovectomy, and arthroscopic local excision. J Bone Joint Surg Am. 1992;74: 119123.

13. Flandry F, Hughston JC. Pigmented villonodular synovitis. J Bone Joint Surg Am. 1987;69:942949.

14. Lee BI, Yoo JE, Lee SH, Min KD. Localized pigmented villonodular synovitis of the knee: Arthroscopic treatment. Arthroscopy. 1998;14:764-768.

15. Gaubert J, Mazabraud A, Verdie JC, Cheneau J. Les synovites villonodulaires he' mo-pigmente' es des grosses articulations. Rev Chir Orthop. 1974;60:265-298.

16. Meehan PL, Daftari T. Pigmented villonodular synovitis pre- senting as a popliteal cyst in a child: A case report. J Bone Joint Surg Am. 1994;76:593-595.

17. Beguin J, Locker B, Vielpeau C, Souquieres G. Pigmented villonodular synovitis of the knee: Results from 13 cases. Arthroscopy. 1989;5:62-64.

18. Howie CR, Smith GD, Christie J, Gregg PJ. Torsion of localized pigmented villonodular synovitis of the knee. J Bone Joint Surg Br. 1985;67:564-566.

19. Breimer $\mathrm{CW}$, Freiberger RH. Bone lesions associated with villonodular synovitis. AJR Am J Roentgenol. 1969;79:618-621.

20. McMaster PE. Pigmented villonodular synovitis with invasion of bone. J Bone Joint Surg Am. 1960;42:1170-1183.

21. Mancini GB, Lazzeri S, Bruno G, Pucci G. Localized pigmented villonodular synovitis of the knee. Arthroscopy. 1998; 14:532-536.

22. Delcogliano A, Galli M, Menghi A, Belli P. Localized pigmented villonodular synovitis of the knee: Report of two cases of fat pad involvement. Arthroscopy. 1998;14:527-531.

23. Bessette PR, Cooley PA, Johnson RP, Czarnecki DJ. Gado- linium-enhanced MRI of pigmented villonodular synovitis of the knee. J Comput Assist Tomogr. 1992;16:992-994.

24. Van Meter CD, Rowdon GA. Localized pigmented villonodu- lar synovitis presenting as a locked lateral meniscal bucket handle tear: A case report and review of literature. Arthroscopy. 1994; 10:309-312.

25. Le Tiec T, Hulet C, Locker B, Béguin J, Vielpeau C. La synovite, villonodulaire du genou: Analyse d'une série de 17 cas et revue de la littérature. Revue de chirurgie orthopédique et réparatrice de l'appareil moteur. 1998;84(7):607-16.

26. Jelinek JS, Kransdorf MJ, Utz JA, Berrey Jr BH, Thomson JD, Heekin RD, Radowich MS. Imaging of pigmented villonodular synovitis with emphasis on MR imaging. American Journal of Roentgenology. 1989 Feb 1;152(2):337-42.

27. Poletti SC, Gates HS, Martinez SM, Richardson WJ. The use of magnetic resonance imaging in the diagnosis of pigmented villonodular synovitis. Orthopedics. 1990 Feb 1;13(2):185-90. 
28. Muscolo DL, Makino A, Costa Paz M, Ayerza MA. Localized pigmented villonodular synovitis of the posterior compartment of the knee: Diagnosis with magnetic resonance imaging. Arthroscopy. 1995;11:482-485.

29. Rao AS, Vigorita VJ. Pigmented villonodular synovitis (giant cell tumor of the tendon sheath and synovial membrane): A review of eighty-one cases. J Bone Joint Surg Am. 1984; 66:76-94.
30. Flandry F, Hughston JC, McCann SB, Kurtz DM. Diagnostic features of diffuse pigmented villonodular synovitis of the knee. Clin Orthop. 1994;298:212-220.

31. Schwartz HS, Unni KK, Pritchard DJ. Pigmented villonodular synovitis: A retrospective review of affected large joints. Clin Orthop. 1989;247:243255. 